\title{
Small Intestinal Mucositis
}

National Cancer Institute

\section{Source}

National Cancer Institute. Small Intestinal Mucositis. NCI Thesaurus. Code C78613.

An inflammatory process affecting the mucous membrane of the small intestine. 